\title{
Crowdfunding: Genesis and Comprehensive Review of Its State in Africa
}

\author{
Oloutchègoun Josias Lawrence Adjakou \\ School of Economics and Management, Chongqing Jiaotong University, Chongqing, China \\ Email: josiasadjakou@gmail.com
}

How to cite this paper: Adjakou, O. J. L. (2021). Crowdfunding: Genesis and Comprehensive Review of Its State in Africa. Open Journal of Business and Management, 9, 557-585.

https://doi.org/10.4236/ojbm.2021.92031

Received: December 23, 2020

Accepted: March 13, 2021

Published: March 16, 2021

Copyright $\odot 2021$ by author(s) and Scientific Research Publishing Inc. This work is licensed under the Creative Commons Attribution International License (CC BY 4.0).

http://creativecommons.org/licenses/by/4.0/

\begin{abstract}
In developing countries, the topic of crowdfunding is still in its infancy because Europe; Asia and North America have monopolized almost all the researchers' attention. Nevertheless, the number of scholars stressing the fact that investigations should be conducted on the economic impact of crowdfunding in developing countries where financial systems are still struggling is incredibly increasing. But before getting to that point, as Gajda and Walton stated, "An analysis of primary and secondary data; in-depth assessment of live projects and statistical analysis could provide more insight (...) how to make crowdfunding more accessible to entrepreneurs in the developing world" (Gajda \& Walton, 2013: p. iii). Drawing on this and the fact that none of the extant literature about crowdfunding in Africa has provided statistical assessment of existing platforms on the continent; how much crowdfunding has been adopted and sustainably implemented across various region on the continent, this paper's main goal is to depict and describe the current situation of crowdfunding in Africa. Known as proven and accepted methods used for growing topics in the field of entrepreneurship, this paper used exploratory and descriptive methods. This paper provides everyone in need of clear understanding of crowdfunding's origin; how it evolved; its level of penetration and use in Africa, with the necessary information. The study came to conclude that in West and North Africa only $22 \%$ and $33 \%$ of the platforms created in the span of 2012 to 2020 are still operating. East Africa and South Africa are doing far better as respectively $70 \%$ and $55 \%$ of their crowdfunding platforms are still operating. The study also found that French Speaking countries struggle a lot in implementing and sustaining crowdfunding platform. West Africa performs very poorly as rarely the projects listed on the scarce platforms still operating manage to gather more than $2 \%$ of their funding goals. The study also came to the conclusion that by May 2020, 64\% of the crowdfunding operating in Africa are foreign based.
\end{abstract}




\section{Keywords}

Crowdfunding, Entrepreneurship, Funding, Equity, Debt, FinTech, Equity

Gap, Africa, Economic Development, Developing Countries

\section{Introduction}

The battle against poverty and underdevelopment in Africa has been going on for centuries now. Figures from scholarly articles; the World Bank Organization and other institutions are glaring. Trying by all means to remediate the persistent problem, African governments as well as policymakers and academics acknowledged the potentiality of entrepreneurship to bring a sustainable solution (Arvanitis, 2015; Adisa et al., 2014). Its paramount importance in meeting economic goals was stressed by many academics in their research works (Acs, Desai, \& Hessels, 2008). Moreover it is widely recognized that entrepreneurship by providing goods or services to fulfill needs, comes along with employment boost (Ayyagari, Dermirguc-Kunt, \& Maksimovic, 2011; Abor \& Quartey, 2010); technological innovation and competition intensification (Brixiova, 2010; Agyapong, 2010; de Bell, 2013) which are important drivers to socio-economic development goals achievement such as poverty reduction (Adisa et al., 2014; Mano, Iddrisu, Yoshino, \& Sonobe, 2012). This directed African governments to encourage small and medium size enterprises creation across the continent. Nowadays small and medium size enterprises are main job creation drivers on the continent. They account for more than $70 \%$ of the employment and over $95 \%$ of the enterprises available on the continent. Yet, poverty alleviation and development across the continent are still delaying. This state of affairs finds its justification in the fact that necessity driven entrepreneurship along with the informal sector is the most promoted in Africa. Filmer and Fox said in 2014 that the informal sector in Africa accounted for more than $80 \%$ of the total workforce and that this figure was not about to decrease in any near future (Filmer \& Fox 2014). In 2010, Brixiova asserted on the same line that necessity-driven entrepreneurship is dominant in developing countries (Brixiova, 2010). In the case of Africa, what favors the development and expansion of the informal sector along the necessity-driven entrepreneurship is the lack of managerial skills and the lack of financial support (Agwu \& Emetc, 2014; Mano et al., 2012). The lack of funding which reveals itself to be the biggest obstacle facing African entrepreneurs in their entrepreneurial journey (Beck \& Cull, 2014; Adebayo \& Nassar, 2014) is a key issue to tackle in order to effectively move toward sustainable development goals as wished. Yet, the funds shortage which induces the huge equity gap the African continent is experiencing, the combination of mobile phone and the access to the internet that in getting more pronounced in recent years across the continent (GSMA Intelligence, 2015; Manyika et al., 2013) provides a unique venue to take advantage of new technological financial means. One in- 
novative form of finance already adopted and proved to be working in developed countries is crowdfunding. Crowdfunding being the fact of raising money through internet platforms to fund a venture without the intervention of any formal financial institution, the World Bank clearly stated in 2013 that "Developing economies have the potential to drive growth by employing crowdfunding to leapfrog the traditional capital market structures and financial regulatory regimes of the developed world" (World Bank, 2013: p. 9). Other financial institutions and scholars also insist on the fact notwithstanding the challenges developing countries may face while attempting to establish crowdfunding as a substitute to traditional financial organism to fund small medium size enterprises, crowdfunding is a great asset that can greatly help African entrepreneurs to mitigate the equity gap on the continent (Berndt, 2016). This being since 2009 the concept gained attention from Africans and some domestic platforms are even being created in Africa to help African entrepreneurs to take full advantage of the fintech. It is unfortunate to note that Africa, the continent which needs the most this kind of asset has not been effectively using it as till now the crowdfunding market share of Africa has not made it up to $0.1 \%$ of the total global market share (Massolution, 2015; P2PMarketdata, 2020). Another fact observed that the extant literature about crowdfunding in Africa is poor. Seeing this state of things, this study aims to stand out by providing a clear literature about what is crowdfunding; how the idea of crowdfunding as financing source did emerge; why it disappeared for a while and what has changed with the new era. The study defined and explained two types of crowdfunding which are Equity and Debt based crowdfunding. The study did document and provide a clear outline of what are the components of a regulated crowdfunding environment before tackling the crowdfunding in Africa. On the African part, this paper did provide an overview of crowdfunding; the current state of crowdfunding in Africa from 2012 to 2020; further this article provides a list of crowdfunding platforms operating on the African continent since 2012 to May 2020 along with statistics of current crowdfunding penetration on the continent. By giving a clear and detailed picture of the extent to which crowdfunding has been adopted in Africa as per 2020, this study aims to help policymakers and practitioners to first understand what is crowdfunding; where it came from; its contingencies; how well did Africa perform in its adoption so far. This paper helps policymakers and practitioners to get a better understanding of crowdfunding in African context and act upon it to design adequate adapted and sustainable crowdfunding model to the good of Africans and the continent.

\section{Introduction to Crowdfunding}

\subsection{The Idea and Emergence of Crowdfunding}

One of the most prominent instances of early type of crowdfunding is the building of plinth upon which the Statue of Liberty is laid. The erection of the pedestal came to pass by means of a crowdfunding resulting from the desperate call to 
the crowd made by Joseph Pulitzer. His heart-breaking words published in New York World on March 16, 1885, were as follow "Let us not wait for the millionaires to give us this money. It is not a gift from the millionaires of France to the millionaires of America, but a gift of the whole people of France to the whole people of America". Following his plea, small contributions were collected from the mass, many people across the country and even beyond the America borders participated with any amount they had. Joseph Pulitzer then publisher at New York World managed to exploit the might of medias to reach the crowd heart to fund the building of the Statue of Liberty's plinth. In fact, after the committee set to erect the Statue of the Liberty donated by France to America used up all their financial resources without finishing the building of the pedestal, the statue conceived by Frédéric Auguste Bartholdi remained in warehouse because of the lack of financing. Notwithstanding the refusal of both US Congress and New York State to back up the construction, thanks to Pulitzer and his smart idea, the now known Statue of Liberty has been built, funded by small donations. This could be seen as the first reward-based crowdfunding as it did pool money from over 125,000 people to fund the project and at the end, to honor the backers, their names were displayed in the newspaper irrespective of the amount of dollars they had contributed.

After the financial crisis of 2008, the crowdfunding concept revealed itself to be a very good and prominent alternative for small and medium size businesses due to all the prudential measures taken by banks and the other traditional financing organism. Resulting consequences of those measures was the difficulty for small and medium size businesses to access funding because Banks then trusted more the worthiness of Big companies than rising ones; Banks could not really assess the solvency of the new born companies or those of small scales. It was then that arose like the savior, the crowdfunding concept which, favored with the context of the time, quickly gained a wide prominence. Cholakova and Clarysse (Cholakova \& Clarysse, 2015) did argument that backers involved in RB crowdfunding participate most of time without any financial incentive whereas on a Debt-Based crowdfunding, investors are filled with a financial return when pulling out their money (Block, Colombo, Cumming, \& Vismara, 2018; Paravisini, Rappoport, \& Ravina, 2016). The first type of crowdfunding can help collect up to $\$ 10,000$ at most while the second one could be used for a maximum of $\$ 25,000$ approximately, and an example of that kind of crowdfunding is illustrated by the platform named Prosper.com (Leung \& Sharkey, 2014). Platforms in UK, France and Australia, raised respectively an average amount of $£ 205,000$ (on Crowdcube platform) (Vismara, 2015); €151,000 through WiSEED (Hervé \& Schwienbacher, 2018); AUD 318,500 (Ahlers, Cumming, Günther, \& Schweizer, 2015). These above figures have forced the conclusion that this new way of financing could help Small and SME to bridge the funding gap. And it was by drawing upon that, Carpenter \& Petersen (2002); Gilbert, McDougall, \& Audretsch (2006) concluded that these observances carry hope with them for new 
companies and innovation which can now have a bright future.

This is why even though it is claimed by the crowdfunding association in England that the first use of crowdfunding was in 1997, scholars argue the concept really bloomed after the 2008 financial turndown.

In spite of the two centuries span since this has been used in the nineteenth century, nowadays the core principle has not changed, and despite the obvious dissimilitude in the current way of applying crowdfunding concept and the way Pulitzer used its own, the stunning resemblance between both ways is to be noted. Both methods implicate calling upon the common public through the most sophisticated mean of information outreaching at the moment to help fund an enterprise in exchange of a reward.

\subsection{Why Has Crowdfunding Disappeared?}

The mechanism of drawing money from the crowd was strengthened by the blue-sky laws across every state in America in 1911. Provisions of blue-sky law could vary from one state to another, but the main and common point of these laws was that securities offerings and sales, brokerage firms and stockbrokers had to be registered. That way, gateway for scams and abuses could be kept under control and everyone could be held answerable for his action.

With the blue-sky laws, intended to protect people, the market place was secured till 1915 when acting like a catalyst, the Investments Bankers Association brought a cataclysm by telling its members they could span the laws and make solicitation via mail. A process as non-transparent as mail for securities offerings could not be policed by regulators, thus questionable stockbrokers invited themselves in the game and issued stock in pointless and fruitless companies. Luring shareholder with cheap securities with easy and juicy return, driven by greed, in the years 1920s, roughly speaking, 20 million could be reckoned as shareholders and the market could estimate the new securities issued at $\$ 50$ billion. The vast majority of those 20 million had borrowed money to invest in stocks as the market was exciting. Later on, loosely half of the new securities became meaningless, what led to market collapsing and the Great Depression that began in 1929. As consequence the crowd reliance on the market also went down the drain; backers and financial institutions that lend them money also lost a lot of money.

\subsection{The Modern Era of Crowdfunding}

In the modern era while faith has been regained in Web operations; internet trade notably e-commerce, keystones were set for not-for-profit basis money pooling. In the wake of this era, Kiva was created in 2005 to serve as bridge between business owners, entrepreneurs from developing countries on one side and people from the United States of America on the other side. Kiva's role being to dig out funding, as such, American could interoperate with people in the developing world who need financing to start an activity to make a living, with- 
out any intermediary. By simply logging in Kiva Web site they could root for someone in a deer need of credit by contributing with the amount of their choices ranging from $\$ 100$ to $\$ 1000$. Kiva at in turn, besides providing entrepreneur's picture, empowers contributors with ways to police the progress of the projects they funded till the repayment of the loan.

Then came in the global financial crisis of 2008 which left substantial damage to everybody but particularly to micro, small and medium size enterprises through consequent loss of investment. Herein it was merely impossible for new business ventures to obtain loan; banks and other financial institutions were considering only those companies that owned larger asset than what they were asking as loan. This left start-ups and innovators with no venues and no ways to capitalize their businesses.

In 2009 while everybody was undergoing bad times and was lacking funds for their project, Perry Chen thought of Kickstarter, to back musicians and artists up. The idea was to make use of artists fan base to financially support their tour or record their music and as compensation, these latter could give a CD, DVD or the movie that was produced to express their gratitude and honor the contributor. One can already see this as a parent of reward or perk-based crowdfunding.

Another thing that facilitates and boosts the acceptance of crowdfunding was the advent of the Web 2.0 famous as social web. The emergence of social medias as LinkedIn, Friendster, Facebook, Twitter brought the world to our homes, in one click one could form connection, build network, interact and share our interests with people that were unknown to him a minute ago. The ascension Web 2.0 installed a trust atmosphere for online operations and this was primordial for perk-based crowdfunding radiation on two ways. First, it enhanced people to identify themselves to others projects therefore to make contributions; second, it contributed to scale the magnitude of each campaign up as people could share their interest with their family as well as people they just met. As consequence this boosted perks or rewards-based crowdfunding audience and notoriety.

Till then due to some regulations enforced by the Securities Exchange Commission intended to regain people confidence in the stock markets, it was illegal in the United States of America to make use of internet to source capital from unaccredited investors by issuing a public solicitation while it was legal to use internet in the same country to support artists and give microloans to people in needs in the developing world. It was so irritating that in August 2010 a group of entrepreneurs decided to take actions on the behalf of entrepreneurs but also on behalf of backers who were also upset for not being able to freely invest in their communities.

The group of entrepreneurs in question gathered and after having scrutinized the Regulation D, they drafted a well-structured proposition of Start-ups exemption law that entitles entrepreneurs to draw on an unrestricted number of people, up to $\$ 1$ million a year, to fund their business. The proposition drafted by that group of entrepreneurs, will later serve as basis for the crowdfunding legislation in the 2012 JOBS Act. All this was happening at the dawn of the Web 
3.0 and one may say this sequence of events plays a great role in the creation of the third type of web where sourcing capital and social web were joint.

In order to have a legal view on their work, nearly all the securities attorneys they consulted told them it was a loss battle even before they started. But they kept on, till they met the Small Business division of the Security Exchange Commission where they have been told to get an Act of Congress before to expect a modification of the law in effect. At this point, with the amount of effort they had put in, they could just abandon, but the determination to improve the critical situation of lack of funding facing American entrepreneur took the best of them. Through hurdles and struggles they manage to defend the Start-up Exemption Framework at the Capitol Hill, they managed to implicate the House of Representatives and the Senate in the talks on how to design a legal environment to monitor crowdfunding in a way it helps to tackle the funding gap, the urgent need of innovation the United States of America was facing then. President Obama signed the JOBS Act 460 days after those entrepreneurs started the journey to the salvation of both investors and entrepreneurs' side. This was the start of the crowdfund investing, securities-based crowdfunding different from the reward-based one. See Figure 1 for a synthetic summary of how far the crowdfunding system has come from its very beginning to the modern era.

\section{Type of Crowdfunding}

\subsection{Equity Based Crowdfunding}

Equity based crowdfunding is a kind of crowdfunding based on investment, it consists in a set of people ploughing money into buying equity like stocks, bonds, in a direct way or indirectly in the nascent enterprise or the existing company. A total amount of $£ 84$ million invested in operations was forecasted for 2014 regarding the quick bloom and spreading estimated at 201\% year-over-year rate of growth (Baeck, Collins, \& Zhang, 2014; Wardrop, Zhang, Rau, \& Gray, 2015). Among the population polled by Baeck, $96 \%$ stated that what encourages them to invest in a project is first, the quality of the team that built up the project along with the attractiveness of the project, what means the ways it is presented, sold; they choices are not ushered by acquaintances. Another $75 \%$ assert what attract them with Equity based crowdfunding are the opportunity it provides them to diversify their portfolio, the convenience of the investment mechanism and the right to monitor what is done with their money. On the same question; $61 \%$ of the backers polled estimate the financial return as their only one motive for adopting equity-based crowdfunding (Baeck et al., 2014). The particularity of this model of crowdfunding is that the amount of capital that can be raised is larger than those reached on debt-based crowdfunding model; for instance, an average of $£ 199,095$ can be drawn over 125 investors (Baeck et al., 2014). All operations in this model are made by mean of a specific platform to equity-based platform, and entrepreneurs seeking funding are from multiple domains ranging from health care to high-tech innovators. 


\begin{tabular}{|c|c|}
\hline 1886 & $\begin{array}{l}\text { The pedestal on which the statue of Liberty gets crowdfunded by New York } \\
\text { Citizens }\end{array}$ \\
\hline 1911 & $\begin{array}{l}\text { Sky blue law across every state in America to monitor securities offerings and } \\
\text { sales }\end{array}$ \\
\hline 1915 & $\begin{array}{l}\text { Investment brokers brought cataclysm to the marketplace by spanning the sky- } \\
\text { blue laws }\end{array}$ \\
\hline 1929 & Beginning of marketplace collapse and beginning of great depression \\
\hline 1997 & First used of crowdfunding in England under the name of association \\
\hline 2000 & $\begin{array}{l}\text { ArtistShare, the first reward based crowdfunding website for music, launches } \\
\text { the dedicated crowdfunding platform to help artists obtain funds }\end{array}$ \\
\hline 2000 & $\begin{array}{l}\text { Internet-enabled giving goes mainstream with the emergence of sites such as } \\
\text { JustGiving }\end{array}$ \\
\hline 2005 & $\begin{array}{l}\text { Kiva launches which is the first major microloan platform for entrepreneurs in } \\
\text { underprivileged countries }\end{array}$ \\
\hline 2006 & $\begin{array}{l}\text { Michael Sullivan, founder of FundaVlog, is credited with coining the term } \\
\text { 'crowdfunding' }\end{array}$ \\
\hline 2006 & $\begin{array}{l}\text { First peer-to-peer lending platform is released with Prosper with the launch of } \\
\text { ZOPA }\end{array}$ \\
\hline 2008 & The economic crisis occurs, big banks begin to cut back small business lending \\
\hline 2008 & Indiegogo launches reward-based crowdfunding platform \\
\hline 2009 & Kickstarter launches reward-based crowdfunding platform \\
\hline 2010 & $\begin{array}{l}\text { AngelList unveils equity-based angel investing. GoFundMe launches charity- } \\
\text { based crowdfunding }\end{array}$ \\
\hline 2011 & Crowdfunder \& CircleUp launch equity-based platforms \\
\hline 2011 & $\begin{array}{l}\text { Obama Administration reveals the Startup America Initiative focused on } \\
\text { rebooting small business }\end{array}$ \\
\hline 2012 & $\begin{array}{l}\text { Obama Administration passes the Jumpstart Our Business Startup Act a.k.a. } \\
\text { JOBS Act }\end{array}$ \\
\hline 2014 & Kickfurther launches first inventory-based crowdfunding platform \\
\hline 2015 & $\begin{array}{l}\text { Title III of the JOBS Act passes allowing non accredited investors to invest in } \\
\text { equity of companies }\end{array}$ \\
\hline
\end{tabular}

Figure 1. Crowdfunding timeline.

In their working paper on Crowdfunding and Financial inclusion; Ivo Jenik, Timothy Lyman, and Alessandro Nava look at equity crowdfunding as a way by which one can capitalize legal enterprises, projects allow to source capital by selling stock shares. For them, this kind of crowdfunding is more adequate for new business ventures and nascent companies because it enables people and organizations to plough money into company whose shares are not traded in stock exchange and in most of cases, the platform that act as an intermediary just get a commission when the campaign is a success (Alessandro Nava \& Ivo Jenik, 2017). Notwithstanding the fact the model of crowdfunding based on equity is a kind of small regarding the size of the whole crowdfunding industry (barely $11 \%$ of funds raised by crowdfunding in 2015), it went through a remarkable surge by outreaching the entire sector of crowdfunding in term of expansion in the same year $(60 \%$ of growth for equity based crowdfunding against $57 \%$ for the whole industry) according to (Crowds, 2016). The figures in term of year-to-year growth equity-based of crowdfunding showed a 295\% increase rate in 2015 
compared to 2014 as per (Zhang, Baeck, Ziegler, Bone, \& Garvey, 2016); 120\% upsurge rate in America mainly USA and Canada in 2015 regarding 2014 growth rate (Wardrop et al., 2016). An overall amount of \$467 million and \$ 64 million were collected respectively in Europe and Asia-Pacific area (regardless of China) in equity crowdfunding in 2015.

Crowdfunding being an up-surging phenomenon, every segments of the industry is in a perpetual innovation cycle, drawing on this Gabison (2015) argues that new sub models have been built within the equity-based model of crowdfunding. Those sub models can be listed as; investor-led model; cooperative model; co-investment model and the club model. The Investor-led model is one in which funder are invited to follow the lead of a certified investor appointed and entitled to bargain investments provision. In a similar way the platform facilitates investments decision making by checking thoroughly every side of each project before proposing them to people likely to invest in those projects; this model enables it members to coinvest along with pre-existing venture capitalist.

To illustrate what may make equity-based crowdfunding more attractive; Kirby \& Worner (2014) said the principal plus of this model is its ability to facilitate capital obtention to business owners and the effectiveness of the brokerage that enables backers to plough money into a new category of assets that brings forward better profit. Regarding new business ventures, innovative projects and their difficulties to access funding, Gubler (2013) assured Equity crowdfunding is a gateway to a greater panel of investors and backers. In the same line, we can affirm this model of equity provide the crowd with an easy way to get to be aware of investment chances, besides that with this model of crowdfunding, backers have the chance to recoup a thousand-fold their initial ante when the enterprise in which they bought shares experience a big boom. On the other side it reduces the Moral Hazard problem, knowing that when a problem will arise, they (backers and entrepreneur) will all bear the hit; at the same time, it relieves a bit entrepreneur because in contrast with debt-based crowdfunding, their responsibility will not be engaged in an unlimited way when failure arises. Mainly in developing countries, equity-based crowdfunding is such an opportunity in the way it offers possibilities to sources capital from all over the world. In addition to all these when a campaign experiences a striking success it attracts great investors because it depicts a promising product or market to come.

Seen under these angles, it may look like equity-based crowdfunding has no shortcomings. Let's not be lured by the attractive side of the model in question. This model of funding based on selling equity to crowd has its downside. First of all because in most of case, it is about innovation, new business ventures, entrepreneurship, there are huge amount of intrinsic risks, nothing guarantees the venture is going to be a success; next, in general, equities bought through this crowdfunding are highly illiquid because entrepreneur focus most of the time on expanding and making bigger the start-up. After the problem of illiquidity, it is to be noted that a large amount of those shares has great chances to be subject to 
dilution when the entrepreneur issues new stocks for new backers to come in. On the other side, due to policies to monitor platforms, regulate crowdfunding in order to prevent fraud and protect investors, entrepreneurs are demanded to disclose many aspects of their businesses and chiefly if it is an innovative idea, there are exposed to an expropriation of their idea because of the risk inherent to disclosure.

\subsection{Debt Based Crowdfunding}

People think of this model as a new way of lending money to people in need of it rather than a totally neo-financial product. Within this concept, network through internet is used to straight connect lenders and borrowers; this enables fundraisers to directly borrow money or lender to directly plough money debt obligations by means of a platform.

The principal objective of these platforms revolving around lending money, three main types of platforms may be identified. The nonprofit types being the first ones, backers there, aim to provide funding without hope of potential return to people that struggle to get access to traditional financing method. Examples of those types of platforms are Kiva and Zidisha; the first one collects money from backers and use existing microfinance building to lend money to people in remote area. The second one is depicted as a philanthropic association direly involved in microlending. Other examples of nonprofit platforms exist, mainly relying on donations, grants and voluntary to function. Aside the nonprofit types, we have the socially oriented lending. These ones are based on the principle of rooting for special communities or region alongside making some little profit. An illustration is MYC4 that enables SMEs to borrow money in some developing country against a small return. The third one is the so-called commercial lending platforms; LendingClub in the USA, Zopa and RainFin respectively in the United Kingdom and South Africa, plus CreditEase in China are some instances of commercial lending platforms.

As one can tap into Debt crowdfunding for a broad range of purpose; three fundamental sub models are distinguished to meet everybody's need. As per Savarese (2015), the sub-model following which individual lenders are allowed to lend money to other individual raising money or other entrepreneurs is called P2P Lending, and the decision of trusting a fundraiser to contribute to a part or to the totality of the amount needed.

Peer-to-Business (P2B) is the sub-category under which companies or any kind of businesses can have a loan from individuals. It is quick and less costly than the traditional means of borrowing money, and this, according to Savarese (2015) makes it a viable alternative to the casual funding method for new ventures and small exiting enterprises seeking to expand their business.

Business-2-Business is as said by the name, a market place for businesses. In this subcategory, the lender is also a business as the borrower, and moreover, it is to be noted that good rates of returns are to be taken into account within this 
model.

In addition to these three subcategories, Debt crowdfunding is composed of a multitude of functional models. Using a legal and regulatory framework, IOSCO along with researchers have come up with a categorization within which the five most important are "guaranteed return"; "offline debt crowdfunding"; "notary model"; "balance sheet lending" and the "client segregated account" (Kirby \& Worner, 2014).

A quick look at the crowdfunding worldwide market shows that Debt crowdfunding has the biggest share, with the leading region that has adopted the most this model being the Asia Pacific region. Among the diverse types of funding provides by internet, P2P loan is ranked the 1st in China, with an informed market volume of US $\$ 52.44$ billion in 2015 (Zhang et al., 2016) compared to 36.16\$US Millions of dollars in North America (Wardrop et al., 2016). In Latin America and the Caribbean, between 2013 and 2015, P2P American High Platforms $\$ 19,430,0002015$ (Wardrop et al., 2016). In Europe, debt crowdfunding is calculated Raised 3.21 billion euros (about 3.6 billion U.S. dollars) in 2015 (European Commission, 2016). P2P Loans Reached 909 million euros (about. US $\$ 1.2$ billion) in the UK in 2015 alone, compared to 547 million euros (about $\$ 700$ million) in 2014 (Zhang et al., 2016).

These figures could be justified by the panel of benefit people can derive from the debt Crowdfunding. The readiness, the efficacity and the viable approach to substitute the existing burdening model of funding that this model represents are some of its assets that make it of higher attractiveness compared to the other forms of crowdfunding. These put aside, this model encompasses the advantages of Donation Based and reward Based crowdfunding. His approach of funding is very inclusive in the way that it allows small enterprises that could not get access to credit due to the size of their enterprise or to the fact that their project is risky and they do not have enough collateral to put on the table to get access to financing. Talking about the benefits of the model Kirby \& Worner (2014) asserted that the P2P lending platforms are gateways to novel types of resources as it provides people with an un-collateralized debt. It also allows nonprofessional funders with savings that are in quest of assets in which to invest, to easily invest their money. Another great benefit of this model could be the higher financial return it comes with. It provides a higher revenue than savings and is suitable for investor seeking for great returns on their investment and that does not have an aversion for risks. According to the European Commission (2016), the low infrastructure cost incurred by platforms enables them to facilitate loans at lower cost to entrepreneurs and could also trigger innovation within the traditional funding organization. The conveniency of this model is depicted by the fact that platforms are accessible to both funders and fundraisers 24 hours a day and 7 days a week. The EBA (2016); Ichiue \& Lambert (2016); OECD (2009); Wehinger (2014) acknowledged how tough it is nowadays for traditional lenders to give a loan to an uncollateralized person or to the SMEs. All these are because of post 
crisis restrictions. But in some markets, the Debt crowdfunding have come to be a sound substitute of Banks and other traditional financial organizations.

Let's screen up the risks associated with this model of crowdfunding. Like every model, there is a risk linked to the debt crowdfunding. But one thing not to forget is that those risks implied both sides; the funder and the fundraiser. The first risk is insolvency; this may lead to a financial loss. This is a consequent risk as the European Commission (2016) said there are no regulations or laws that protect those investments. Another risk is the risk of illiquidity, where backers could not withdraw their money before the loan maturity, to these can be added the risk of bearing a higher cost at time compared to the other usual financial institution and the weak protection faced by investors.

\section{Components of a Regulated Crowdfunding Ecosystem}

A regulated crowdfunding is a monitored online venue where one can vend stocks and obligations to groups of people willing to invest. In addition to delineating the posture to be adopted between brokers; backers and companies, those in charge of regulating securities also control the regulated crowdfunding (Figure 2). It is very substantial that actors within the crowdfunding environment get to fully understand the mechanism of the system.

The objective related to the ecosystem of the crowdfunding is to facilitate the cooperation between backers and emitters, to help them to quickly get along in the most effective and efficient way.

In each jurisdiction, specific government instruct a security commission to administrate the buying and selling of shares and debts instruments along with enforcing and dealing with the application of security regulation within their jurisdiction. The commission is in charge of policing who can invest; which emitter can take part and how platform administrators run and report back to the security commission about their business. Their purpose is to create a risk-free environment for investors and to make sure the marketplace is not disturbed.

Accredited investors are individuals willing to plough money into shares or debt instruments and considered enough rich to an extent which they would not be deeply financially affected in case an investment goes wrong. Those sponsors are deemed to have enough awareness and financial knowledge to make good decision about what to put their money into. A study has revealed that only within $3 \%$ to $5 \%$ of the world population is judged to be accredited as investors and more surprising is that most of those people considered as accredited to invest do not get the chance to grab investment opportunities in private financing market.

Non accredited investors are the set of individuals leftover after putting aside the $3 \%$ to $5 \%$ of the global population that are qualified to be accredited investors. Most of time it is the remaining part of the population that are not in accordance with the standard required to be sophisticated investors and that have at least 18 years old; taking this into consideration; regulation setters allow them to also 


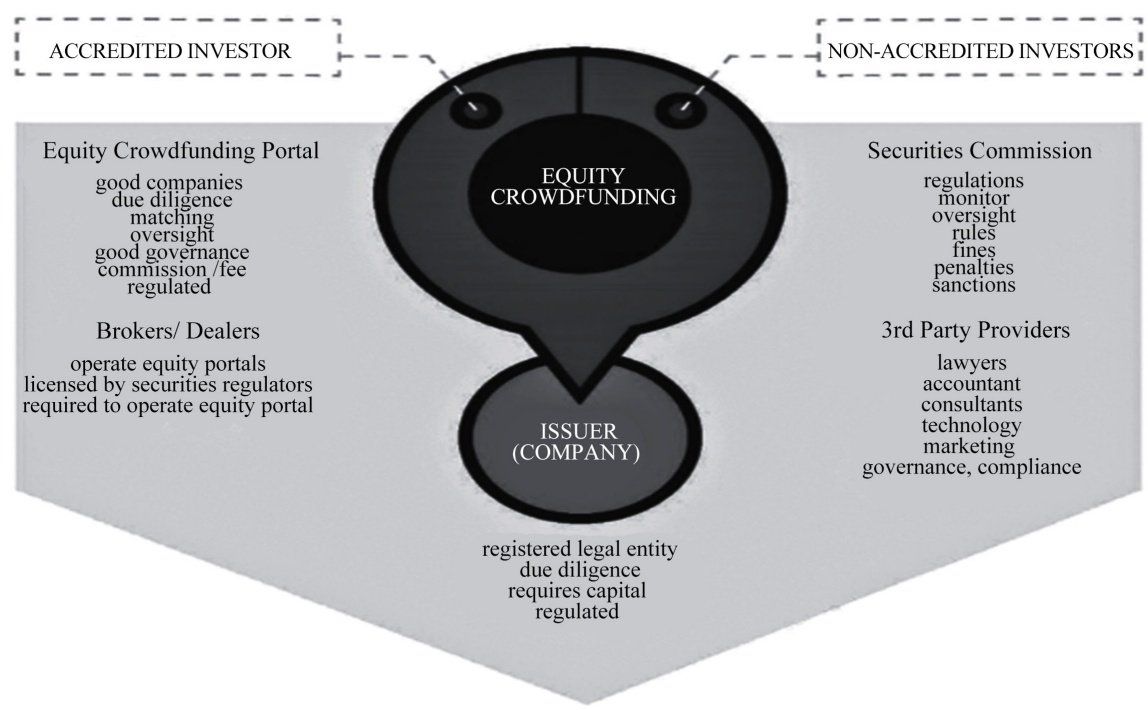

Figure 2. Crowdfunding ecosystem participants and responsibilities; Source (Jofre, 2016).

invest under a set of restrictions concerning the amount of money they are authorized to plough into a venture. The lawmakers have put this system in place to shelter non accredited investors against critical blow when a venture in which they have put money does not work out. Some countries are already thinking about alleviating the restrictions on the amount of fund non accredited investors can invest, in order to allow them to invest more. But this will be effective when regulators think the crowdfunding ecosystem is enough safe and stable for people that are not that much rich and that does not have sophisticated knowledge in financial investment.

A regulated crowdfunding portal has the mission to connect fundraisers with individual with a financial surplus willing to invest. A regulated crowdfunding portal has the obligation to make sure all the issuers on their platforms complied with the regulations into force within their jurisdiction. Individual who operates legal crowdfunding portals are obliged to be registered brokers and they have the responsibility of screening all the issuers application to assess their solvability and their reliability in order to protect investors that use their portals to make investment. The portal also has to be registered with securities commission. At last the portal can choose to be specialized in one or many domains. Some examples of segment of specialization of regulated crowdfunding around the world are mobile apps; real estates; restaurants; oil and gas; technology; life sciences and so on.

Issuers are individuals or companies in need of funds, who trade securities against capital. Due to the fact that a good regulated crowdfunding enables fundraisers to directly be in touch with the funders; it relieves issuers from the burden of the traditional financial intermediaries, reduce cost and allow people with low collateral and people that would not have access to finance with banks or other traditional institutions to have access to funding. However, the major re- 
quirement enforced on them are the transparency and the disclosure obligation, in order to keep every participant at the same level of information and to enhance trust among them.

The last part of a regulated crowdfunding ecosystem is the set of third-party providers. That part encompasses lawyers, accountants and others. They are also a very important component of the regulated crowdfunding ecosystem in the way that, to assess creditworthiness of an issuer or to assess the compliance of what an issuer is issuing with the regulatory standard, fundraisers may be asked to provide some audited financial statement or even some legal documents.

\section{Overview of Crowdfunding in Africa}

The infancy stage of crowdfunding in Africa makes both the demand and supply level of its market very low on the continent. China and the Asia Pacific region still lead the global crowdfunding market in 2018 with a global share of $70.7 \%$ and a total amount of $\$ 215.4$ billion raised. After comes the American region which encompasses the Latin America; the Caribbean; the United States and Canada with a worldwide market share of $20 \%$ corresponding to a financial volume of $\$ 61.1$ billion. The European along with the United Kingdom accounted for $3.4 \%$ with a total amount of $\$ 10.4$ billion raised in 2018. The precise global market share of Crowdfunding campaigns run by Africans is $0.07 \%$ by the end of 2018 with more $50 \%$ of this share raised by platforms based outside the continent (P2PMarketdata, 2020).

The facts that since 2014 till 2019 the worldwide combined African crowdfunding market share remained less than $0.1 \%$ of the crowdfunding global volume (Massolution, 2015; P2PMarketdata 2020) denotes the broad unexploited financial asset which is the crowdfunding yet to be explored by Africans. Although the growth by $101.5 \%$ of crowdfunding volume in 2018 in Africa after the decrease of $42.8 \%$ the African market share encountered in 2017, it is obvious that the African part in the crowdfunding market is a chicken feed and that this financial alternative still has a long way to go in Africa in order to live up to its full promises.

In 2016 Afrikstart asserted there were 39 active platforms in Africa (Afrikstart, 2016) against 19 reported by Massolution in 2014 (Massolution, 2015); 25 reported by Allexander Hiller in 2017 (Hiller, 2017). A personal investigation helped to count 64 platforms through Africa by May 2020. Most of the platforms are domiciliated in South Africa; Kenya; Nigeria; Egypt and Zambia. Notwithstanding the number of platforms existing across the continent, intercontinental crowdfunding platforms are preferred by Africans for their crowdfunding campaigns, see Figure 3 and Figure 4. Figure 3 shows that over the 126.9 million that were raised in 2015; 94.4 million were raised on international platforms. Figure 4 further supported the fact that Africans tend to use more international platforms by showing that $73.9 \%$ of the funds raised through crowdfunding that year was on international platforms. Domestic platforms do not manage to get 
enough attention from people inside their country or the continent. The majority of Africans crowdfunding campaigns taking place on intercontinental platforms do not enable African to fully exploit the potential of the fintech. Due to legal constraints helping to monitor the crowdfunding environment on those continents, Africans cannot participate in certain types of crowdfunding like the equity-based and the debt-based ones to fund innovative projects on the intercontinental platforms, see Figure 5. This being the main focuses of crowdfunding campaigns conducted by African are on charity and at some extent on necessity-driven entrepreneurship (Fleming \& Sorenson, 2016; Gajda \& Walton, 2013; Hemer et al., 2011; Mollick, 2014; Vulkan et al., 2016; World Bank, 2013; FSD Africa, 2017) by means of donation-based and reward-based crowdfunding.

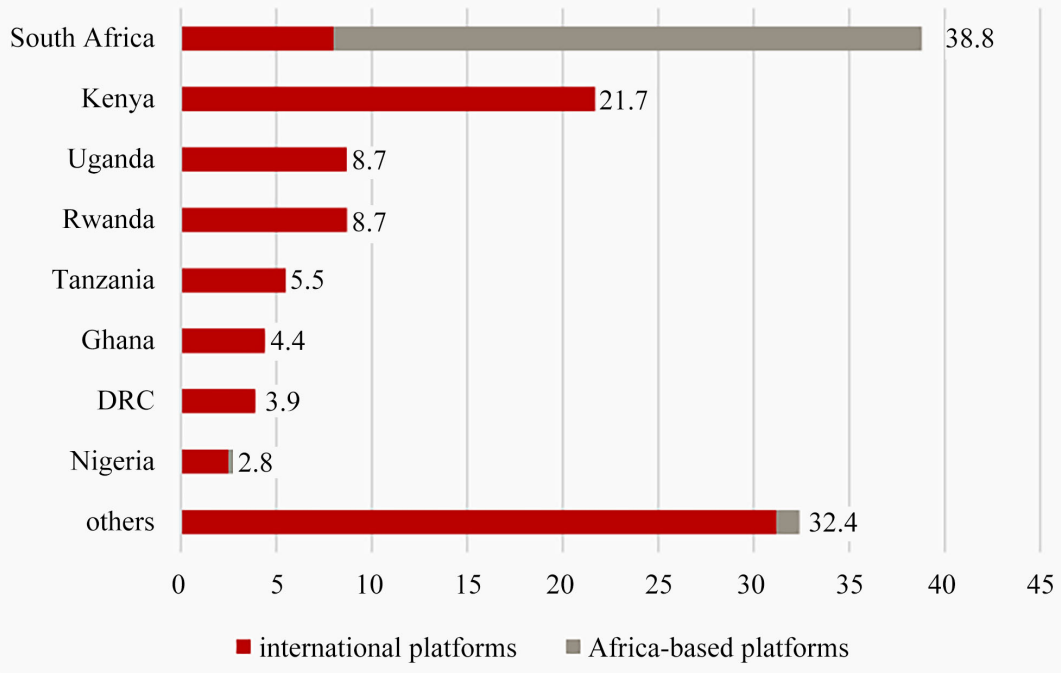

Figure 3. Funds raised via crowdfunding by country (in million USD) in 2015; Source: (Disse \& Sommer, 2020).

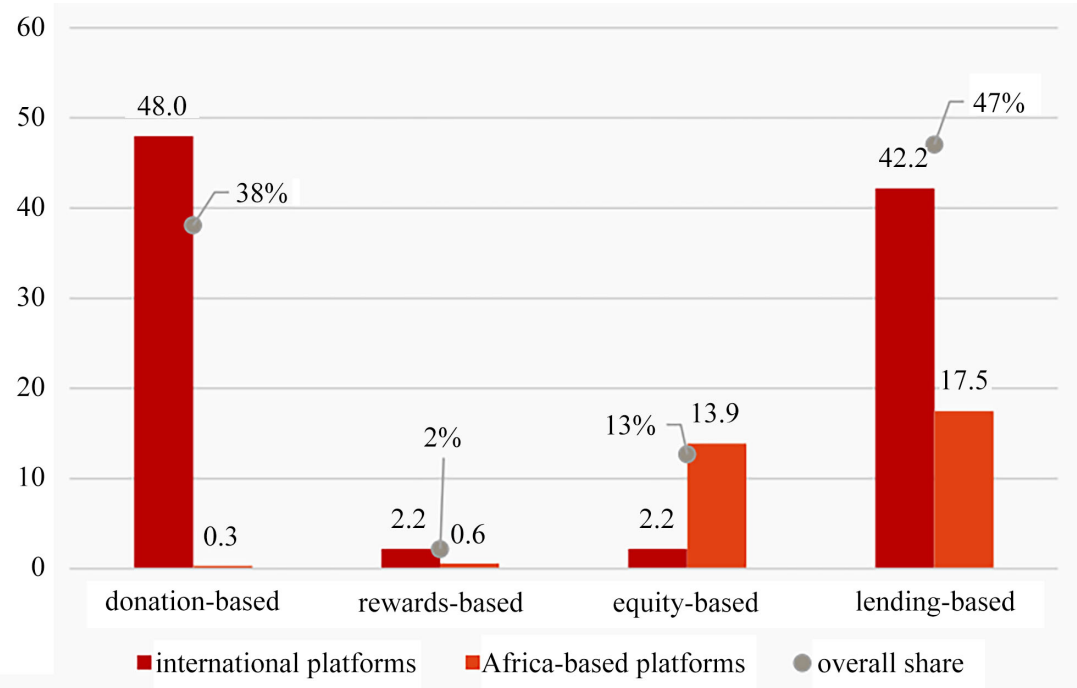

Figure 4. Funds raised by type of crowdfunding platform (in million USD) and overall share (in percent) in 2015; Source: (Disse \& Sommer, 2020). 


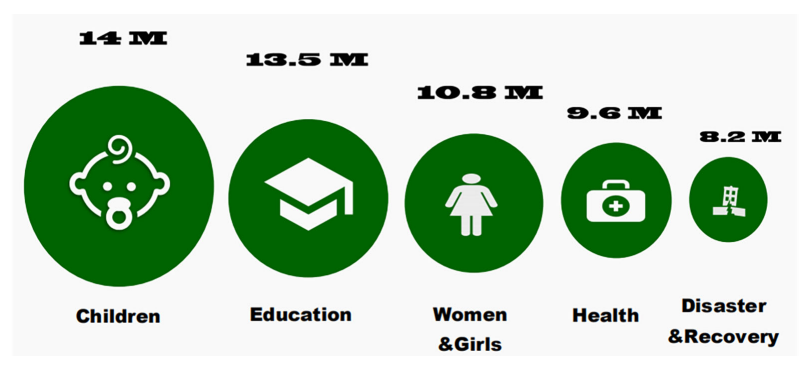

Figure 5. Most funded projects from international platforms operating in Africa in 2015; Source: (Afrikstart, 2016).

\section{Current States of Crowdfunding in Africa}

Based on data observations it is obvious that crowdfunding market in East Africa and South Africa is more mature than in Ouest Africa. In $2015 \$ 38.8$ million were raised in South Africa via crowdfunding; $\$ 44.6$ million in East Africa against only $\$ 7.3$ million in Ouest Africa (Disse \& Sommer, 2020; Afrikstat, 2016). Money raised on international platforms in 2015 accounted for $74.38 \%$ (Disse \& Sommer, 2020) while the remain 25.62\% where raised on Africa based platforms. Top recipient countries of fund from foreign platforms in 2015 were Kenya; Rwanda; Uganda; South Africa; Tanzania; Ghana; D.R. Congo and Nigeria, see Figure 6. Data on Figure 7 displayed top foreign platforms operating in Africa in 2015. A quick tour of those platforms allows to say that all of them operate in English and this can partly explain the fact there is nearly no existent crowdfunding market in French speaking countries in West Africa.

The Cambridge Center for Alternative Finance 2020 in their report on the Global Alternative Finance showcased some countries fact sheets. It can be seen that Botswana has managed to raise respectively $\$ 2.4$ million and 15.4 million via crowdfunding in 2017 and 2018. Kenya managed to raise \$13 million; \$20 million and \$35 million via crowdfunding in 2016; 2017 and 2018. Even though South African crowdfunding market is supposed to be the most mature in Africa, their financial volume is declining. They pooled \$34 million in 2016; \$16 million in 2017 and $\$ 28$ million in 2018. One may easily say that Crowdfunding is gaining more awareness in Uganda as the financial volume of crowdfunding in the country is increasing; \$4 million in 2016; \$6 million in 2017 and \$17 million in 2018. The most astonishing African country with an exponential growth on the crowdfunding market is Zambia, with repective amounts of $\$ 0.9$ million in 2016; \$1.8million in 2017 and a huge bond to \$41 million in 2018 (Zigler et al., 2019).

By October 2020 data retrieved from THECROWDDATACENTER report 135 projects across Nigeria in 2019 which helped to raise a total of $\$ 22,765$. The Crowdfunding data center went further stipulating that in 2019 Nigerians got only $1 \%$ of success rate on all the campaigns instigated (The Crowd Data Center, 2020a). Still in Ouest Africa, only 1 crowdfunding project was launched in Benin in 2019 without success with a total amount of $\$ 0$ raised. More interesting, 


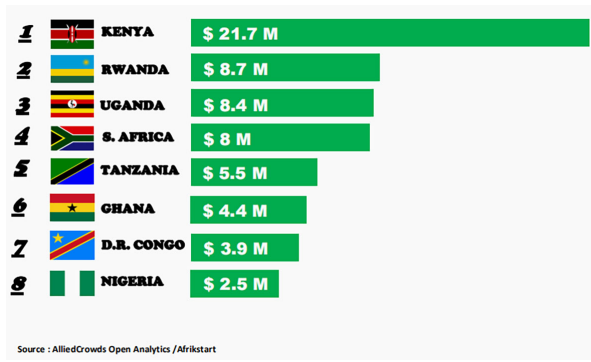

Figure 6. Top recipient countries of funds from foreign platforms in 2015; Source (AlliedCrowds Open Analytics/Afrikstart).

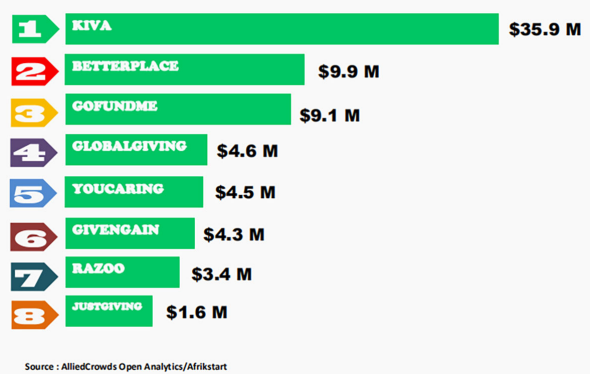

Figure 7. Top foreign platforms operating in Africa in 2015; Source: (Afrikstart, 2016).

besides Benin and Nigeria, no crowdfunding campaigns were started in the other west African countries in 2019. This picture is how ignorant people are still about crowdfunding in West Africa. In the most mature crowdfunding market so far in Africa, the South African market, only 188 crowdfunding campaigns took place in 2019 with a success rate of $7 \%$, raising a total amount of $\$ 694,429$. Kenya did not do better in term of success rate over its 74 projects in 2019, pooling together a total of $\$ 921,793$. Rwanda with the same rate of success as Benin republic over the 6 projects launched in the country has nevertheless managed to gather $\$ 1165$ in 2019. Burundi joined Benin Republic and Rwanda line with a $0 \%$ of success rate with $\$ 0$ raised on the 2 campaigns started in the country (The Crowd Data Center, 2020b). In 2019 Tanzania raised \$11,977 from 17 projects with a success rate of $5 \%$. Tanzania stands out with the highest success rate on crowdfunding projects in Africa in 2019 which is $17 \%$ over the 12 campaigns instigated in the country which helped to raise a total of $\$ 19,241$ (The Crowd Data Center, 2020c).

\section{Summary of Platforms with an Africa Focus from 2012 to 2020 and Statistics}

\subsection{Example of Crowdfunding Platforms in Africa}

\section{Platforms in Egypt.}

- Arab Crowdfunding: (Yes)

Based in Egypt Arab crowdfunding is a website dedicated to Arab crowdfunding as the name suggests. Through this platform, Arab investors lend mon- 
ey to Arab fundraisers in North Africa and in the Middle east. Their platform is available at www.arabcrowdfunding.com.

- Shekra (No)

Founded in January 2012, their motto is "Be part of the next success story". As one of the leading crowdfunding platforms in Egypt, their attribute is to match nascent startups with investors. The platform is available at www.shekra.com. As per May 2020, the website was under renovation.

\section{Platforms in Ghana:}

- Farmable (No)

The vision of this platform is to fight hunger without relying on external aids. This being the crowdfunding platform was created to build a self-sustaining enterprise to empower small farm holders by equipping them with the necessary tools and resources to ease their life. A correlated goal is also to try to build a sustainable food supply community in Ghana by Ghanaian. The platform is available at www.farmable.me.

- Kwidex (Yes)

With a charming platform, their tagline says "Make an impact and earn rewards for it". The main goals of Kwidex are to reduce poverty; increase food security and at the same time make people earn extra income. They focus on giving support only to innovative ideas in the field of agriculture in Ghana. Their website is www.kwidex.com.

- SlizeBiz (No)

This is the first Ghanaian platform. It is based in Accra and concentrates more on financing innovative ideas by leveraging African backers and Angel investors. No list of ventures in which investors could easily invest has yet been unveil. Till November 2019 SlizeBiz has not yet been launched as the first launching scheduled for March 2014 in New York City had been postponed. www.slicebiz.com

Platforms in Kenya:

- M-Changa (Yes)

The motto of this platform is "Harambee" which means "pulling together" in Swahili to illustrate the fact that solidarity of many people could contribute to concretizing the dream of a whole community. M-Changa is a platform that aims to provide entrepreneurs with a mean of funding their projects by leverage mobile technology. They are available at www.changa.co.ke.

- Lelapa Fund (Yes)

The word Lelapa means "community" or "home" in Setswana. This platform based in Kenya reaches out for African SMEs and women by providing an investment platform which helps to connect investors and African companies. The platform focuses on technological sector and on fast moving Consumer Goods. There are available at www.lelapa.co.

Platforms in Nigeria:

- Naija Fund (Yes)

This is a donation-based platform based in Nigeria founded in 2015. Its goal is 
to connect fundraisers for social cases to donators from all over the world. Their website is www.naijafund.com.

\section{- Donate NG (Yes)}

The motto is "Fundraise for charitable projects". With this tagline, the message about this platform's goal is clear. They deal with charitable projects and personal social causes since 2015. The platform is available at www.donate-ng.com.

\section{Platforms in South-Africa:}

- FundFind (No)

Founded in 2013, this Platform set up in South Africa is a reward Based one and uses the "Keep-it-all" and the "All-or-nothing" methods. The platform does not make a list of the number of unsuccessful campaigns but it does about the successful ones. We could count project ranging from backing artists to produce their albums, donations to support teaching internship, some medical ventures such as buying medical equipment for child and even fund was raised for a treatment against cancer. The platform is available at www.fundfind.co.za.

- Jumpstarter (Yes)

This platform founded in 2012 and owned by south African have managed to collect about $€ 5000$ result of 23 campaigns as of November 2019. No information has been revealed about how much the platform charges in commission and there is no information about how the platform operates. They are available at www.jumpstarter.co.za.

The following Table 1 and Table 2 are respectively the updated list of domestic crowdfunding platforms (created and based in Africa) spanning 2012 to 2020 and the updated list of international based platforms operating in Africa.

Table 1. Updated list of domestic Crowdfunding platforms (created and based in Africa) from 2012 to 2020.

\begin{tabular}{|c|c|c|c|c|c|c|}
\hline Country & Platform Name & Date of Foundation & Model & Available at & & Active \\
\hline \multirow{13}{*}{ South Africa } & backabuddy & 2007 & Donation-based & www.backabuddy.co.za & 1 & yes \\
\hline & Citysoirée & 2010 & Reward-based & www.citysoiree.co.za & 2 & no \\
\hline & Islamic Relief SA & 1984 & Donation-based & crowdfund.islamic-relief.org.za & 3 & yes \\
\hline & Lendico & 2013 & Debt-based & www.lendico.com & 4 & No \\
\hline & Livestock Wealth & 2014 & Equity-based & www.livestockwealth.com & 5 & yes \\
\hline & Rafinin & 2012 & Debt-based & www.rainfin.com & 6 & yes \\
\hline & Realty Africa & 2014 & Real Estate-based & www.realtyafrica.com & 7 & yes \\
\hline & StartMe & 2012 & Reward-based & www.startme.co.za & 8 & no \\
\hline & Thundafund & 2012 & Reward-based & www.thundafund.com & 10 & yes \\
\hline & The People's Fund & 2017 & & www.thepeople.co.za & 11 & yes \\
\hline & Uprise Africa & & & www.uprise.africa & 12 & yes \\
\hline & Wealth Migrate & 2014 & Real Estate-based & www.wealthmigrate.com & 13 & yes \\
\hline & ChangeLivesNow & 2010 & Donation-based & www.changelivesnow.co.za & 14 & No \\
\hline
\end{tabular}




\section{Continued}

\begin{tabular}{|c|c|c|c|c|c|c|}
\hline & Edufunder & 2014 & Donation-based & www.edufunder.xyz & 15 & No \\
\hline & Ripple & 2015 & Donation-based & www.ripple.org.za & 16 & No \\
\hline & Rlabsmtoto & 2009 & Donation-based & www.rlabsmtoto.org & 17 & No \\
\hline & Trevolta & 2013 & Donation-based & www.trevolta.com & 18 & No \\
\hline \multirow{11}{*}{ Nigeria } & Different.org & 2015 & Donation-based & Different.org & 19 & Yes \\
\hline & Kwikudi & 2015 & Donation-based & www.kwikudi.com & 20 & yes \\
\hline & PitchOffice & 2013 & Equity-based & www.pitchoffice.com & 21 & No \\
\hline & 234Give & 2012 & Donation-based & www.234give.com & 22 & No \\
\hline & Cfundin & 2015 & Debt-based & www.cfundin.com & 23 & No \\
\hline & Finofund & 2014 & Reward-based & www.finofund.com & 24 & No \\
\hline & Funda Solva & 2014 & Donation-based & www.fundasolva.com & 25 & No \\
\hline & HelpFundNg & 2015 & Donation-based & www.helpfundng.com & 26 & No \\
\hline & Imeela & 2016 & & imeela.com & 27 & No \\
\hline & Naturfund & 2015 & & www.naturfund.com & 28 & No \\
\hline & Funmilowo & & Donation-based & www.funmilowo.com & 29 & No \\
\hline \multirow{2}{*}{ Uganda } & Akabbo & 2014 & Donation-based & www.akabbo.ug & 30 & Yes \\
\hline & $\mathrm{UCN}$ & 2014 & Equity-based & ucn.crowdfundhq.com & 31 & no \\
\hline \multirow{2}{*}{ Zimbabwe } & Fund4Crowd & 2014 & Donation-based & www.f4c.co.zw & 32 & yes \\
\hline & Tswanda & 2014 & Donation-based & www.tswanda.co.zw & 33 & No \\
\hline \multirow{5}{*}{ Ivory Coast } & Orange Collecte & 2013 & Donation-based & www.collecte.orange.com & 34 & no \\
\hline & Happy Benky & & & www.happybenky.ci & 35 & no \\
\hline & InvestirEnsemble & 2018 & & www.investirensemble.ci & 36 & yes \\
\hline & Seekewa & & & www.seekewa.com & 37 & No \\
\hline & Oukaley & 2015 & & www.oukaley.com & 38 & No \\
\hline \multirow{3}{*}{ Togo } & ALODO & & & www.myalodo.com & 39 & No \\
\hline & MIVAFUNDING & & & www.mivafunding.com & 40 & No \\
\hline & Jaappalé & & & www.jaappalé.org & 41 & No \\
\hline Mauritius & Malaik & 2015 & Equity-based & & 42 & No \\
\hline \multirow[t]{2}{*}{ Tanzania } & FundedbyMe & 2012 & & www.fundedbyme.com & 43 & Yes \\
\hline & Lendahand & & & www.lendahand.com & 44 & yes \\
\hline \multirow[t]{2}{*}{ Kenya } & PesaZetu & 2015 & Debt-based & & 45 & yes \\
\hline & Solvesting & 2015 & Debt-based & www.solvesting.com & 46 & no \\
\hline \multirow[t]{3}{*}{ Maroc } & Smala\&Co & & & www.smalaando.com & 47 & No \\
\hline & Atadamone & 2014 & & www.atadamone.com & 48 & No \\
\hline & Cotizi & & Donation-based & www.cotizi.com & 49 & Yes \\
\hline \multirow[t]{3}{*}{ Egypt } & Tennra & 2015 & Donation-based & www.Tennra.com & 50 & No \\
\hline & Yomken & 2012 & & www.yomken.com & 51 & Yes \\
\hline & Madad & 2015 & Donation-based & www.madad.com & 52 & No \\
\hline Algeria & Chikry & 2014 & & www.chikry.com & 53 & No \\
\hline
\end{tabular}


Table 2. Up to date list of international based platforms operating in Africa.

\begin{tabular}{|c|c|c|}
\hline & Platform Name & Country of Operation \\
\hline 1 & Kiva & South Africa, Rwanda, Kenya, Tanzania, Uganda \\
\hline 2 & BetterPlace & \\
\hline 3 & GoFundme & Rwanda, Kenya, Tanzania, Uganda \\
\hline 4 & GlobalGiving & South Africa, Rwanda, Kenya, Tanzania, Uganda \\
\hline 5 & Razoo & South Africa, Rwanda, Kenya, Tanzania, Uganda \\
\hline 6 & JustGiving & South Africa, Rwanda, Kenya, Uganda \\
\hline 7 & 4just1.com & South Africa, Kenya, Tanzania \\
\hline 8 & Ammado & South Africa, Kenya, Rwanda, Tanzania \\
\hline 9 & Awesome Foundation & Uganda, Kenya \\
\hline 10 & Bid Network & South Africa, Rwanda, Tanzania, Kenya, Uganda \\
\hline 11 & Buck4Good & South Africa, Kenya \\
\hline 12 & Chuffed & Kenya, Tanzania, Uganda \\
\hline 13 & Common Sites & South Africa, Tanzania, Kenya \\
\hline 14 & CrowdRise & Rwanda, South Africa, Uganda, Tanzania, Kenya \\
\hline 15 & Crowdfunder & Rwanda, South Africa, Tanzania, Kenya \\
\hline 16 & Freudon & Kenya, Uganda \\
\hline 17 & Fundly & South Africa, Rwanda, Kenya, Tanzania, Uganda \\
\hline 18 & Generosity & South Africa, Rwanda, Tanzania, Uganda \\
\hline 19 & Give Forward & South Africa, Kenya, Uganda \\
\hline 20 & GivenGain & South Africa, Rwanda, Kenya, Tanzania, Uganda \\
\hline 21 & Givology & Rwanda, Kenya, Tanzania, Uganda \\
\hline 22 & Indiegogo & South Africa, Rwanda, Tanzania, Uganda, Nigeria \\
\hline 23 & Kangu & Kenya, Uganda \\
\hline 24 & KickStarter & South Africa, Kenya, Tanzania, Uganda, Nigeria Ghana \\
\hline 25 & OnePercentClub & South Africa, Rwanda, Kenya, Tanzania, Uganda \\
\hline 26 & Patreon & South Africa, Kenya \\
\hline 27 & PifWorld & South Africa, Kenya, Tanzania, Uganda \\
\hline 28 & RocketHub & South Africa, Kenya \\
\hline 29 & SunFunder & Rwanda, Kenya, Tanzania, Uganda \\
\hline 30 & Trine & Kenya, Tanzania, Uganda \\
\hline 31 & Ulule & South Africa, Rwanda, Kenya, Tanzania \\
\hline 32 & Watsi & Kenya, Tanzania \\
\hline 33 & Yewou & South Africa, Rwanda, Kenya \\
\hline
\end{tabular}




\section{Continued}

\begin{tabular}{lcc}
\hline 34 & YouCaring & South Africa, Rwanda, Tanzania, Uganda \\
35 & Waalam Invest & Gabon, Mauritius, Cameroon \\
36 & AfrikLevier & Togo, Senegal \\
37 & FIATOPE & Madagascar, Cameroon \\
38 & Iroko project & Senegal, Ivory Coast \\
39 & Bit Bond & Kenya \\
40 & StartSomeGood & Ghana, Haiti \\
41 & SeedGrants & Kenya, Uganda \\
42 & Zidisha & Zambia, Ghana, Kenya \\
43 & Kopernik & Kenya \\
44 & IndieVoices & Kenya, Nigeria \\
45 & GridShare & Kenya, Rwanda, Ghana \\
46 & 2aid.org & Uganda \\
47 & Babyloan & Uganda \\
48 & Homestrings & Uganda \\
49 & EmergingCrowd & South Africa \\
\hline
\end{tabular}

\subsection{Statistics}

It came out from personal investigations and observations that Africa has registered a total of 64 crowdfunding platforms spanning the period of 2015 to 2020. Out of 10 crowdfunding platforms created in East Africa from 2015 to 2020, 7 are still active while the 3 others are inactive. In South Africa 55\% of the 22 platforms created from 2015 to 2020 are still operating, the remaining 45\% (12 platforms) are now out of service. On the other hand, respectively $67 \%$ and $78 \%$ of platforms created in North Africa and West Africa during these five last years are now out of service. Only 5 platforms (22\%) out of the 23 recorded in West Africa and 3 platforms (33\%) out of the 9 recorded in North Africa within that period of time are still operational. See Figure 8 and Table 3.

The study found out that over the 76 platforms currently functioning on the African crowdfunding market, $64 \%$ are base outside the continent making up to 49 over 76 platforms. Only 27 platforms representing $36 \%$ of the total platforms operating are domestic platforms. See Table 4 and Figure 9. Among the 76 functional platforms; 66 operates exclusively in East and South Africa, only 10 platforms which accounts for only $13 \%$ operates in West and North Africa, see Figure 10 and Table 5 . Further, the study pointed out that only $8 \%$ of the total operating platforms in Africa in 2020 focused on French speaking countries. The remaining 92\% accounting for 70 platforms has an English-speaking country focus, see Figure 11 and Table 6. 


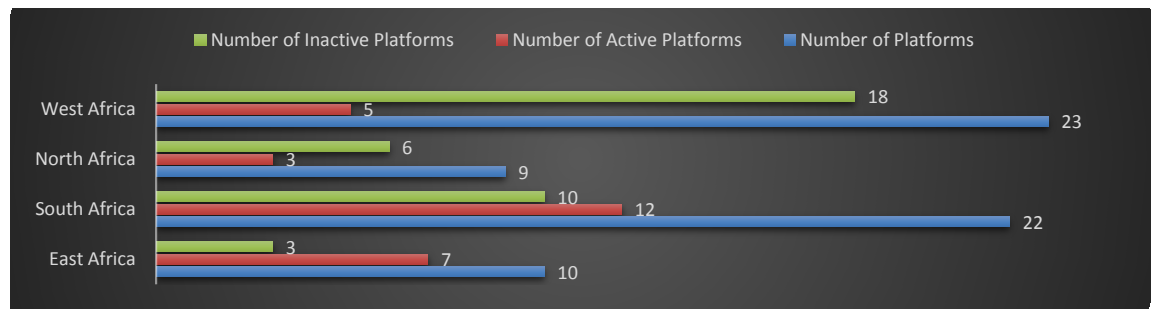

Figure 8. Number of domestic active and inactive platforms per region in Africa from 2015 to 2020 .

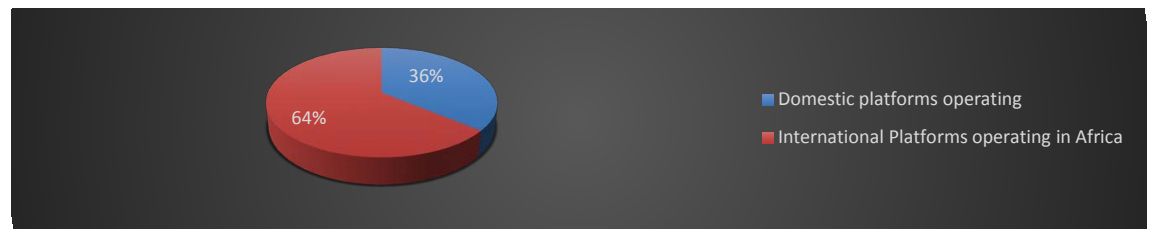

Figure 9. Respective share of domestic and international crowdfunding platforms among the total platforms currently operating in Africa.

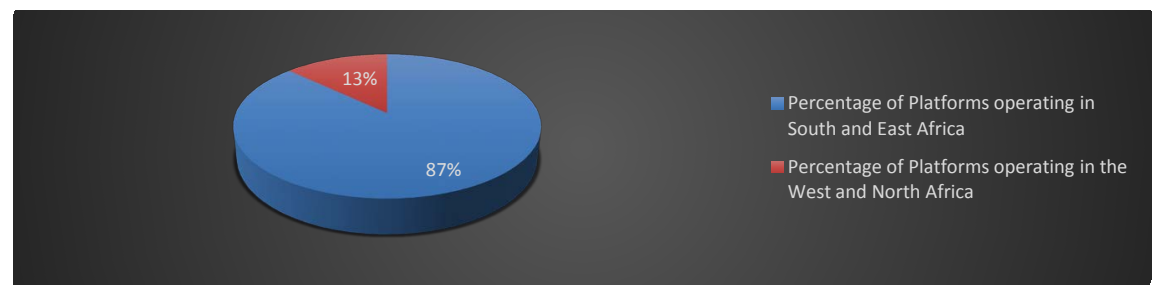

Figure 10. Percentage of platforms operating in South and East Africa against percentage of platforms operating in Ouest and North Africa as per 2020.

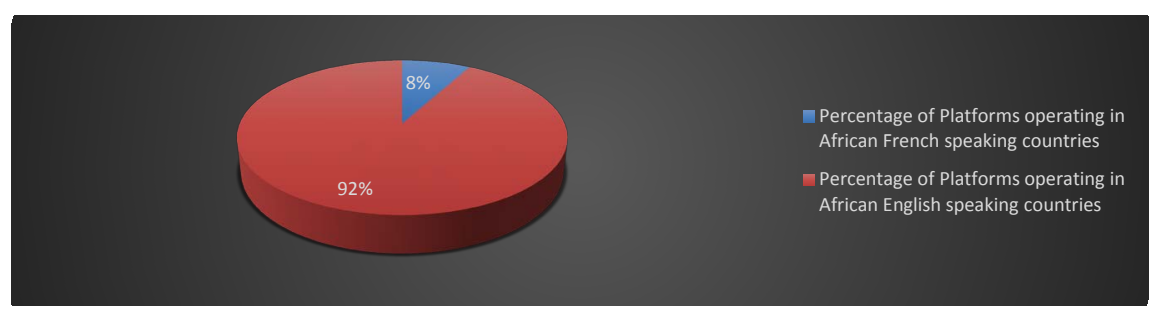

Figure 11. Percentage of platform operating in African French speaking countries and English-speaking countries as per 2020.

Table 3. Number and percentage of domestic active and inactive platforms per region in Africa from 2012 to 2020.

\begin{tabular}{cccccc}
\hline & $\begin{array}{c}\text { Number } \\
\text { of } \\
\text { Platforms }\end{array}$ & $\begin{array}{c}\text { Number of } \\
\text { Active } \\
\text { Platforms }\end{array}$ & $\begin{array}{c}\text { Number } \\
\text { of Inactive } \\
\text { Platforms }\end{array}$ & $\begin{array}{c}\text { Percentage } \\
\text { of Active } \\
\text { Platforms }\end{array}$ & $\begin{array}{c}\text { Percentage } \\
\text { of Inactive } \\
\text { Platforms }\end{array}$ \\
\hline East Africa & 10 & 7 & 3 & $70 \%$ & $30 \%$ \\
South Africa & 22 & 12 & 10 & $55 \%$ & $45 \%$ \\
North Africa & 9 & 3 & 6 & $33 \%$ & $67 \%$ \\
West Africa & 23 & 5 & 18 & $22 \%$ & $78 \%$ \\
\hline
\end{tabular}


Table 4. Number of domestic and international platforms currently operating in Africa followed by percentage.

\begin{tabular}{ccc}
\hline & Number of Platforms Operating in Africa & Percentage \\
\hline Domestic platforms & 27 & $36 \%$ \\
International Platforms & 49 & $64 \%$ \\
\hline
\end{tabular}

Table 5. Number of platforms operating in South and East Africa against percentage of platforms operating in Ouest and North Africa as per 2020.

\begin{tabular}{ccc}
\hline & Number of Platforms & Percentage \\
\hline Operating in South and East Africa & 66 & $87 \%$ \\
Operating in the West and North Africa & 10 & $13 \%$ \\
\hline
\end{tabular}

Table 6. Number of platforms operating in African French speaking countries and English-speaking countries followed by percentage as per 2020.

\begin{tabular}{lcc}
\hline & Number of Platforms & Percentage \\
\hline Operating in African French speaking countries & 6 & $8 \%$ \\
Operating in African English-speaking countries & 70 & $92 \%$ \\
\hline
\end{tabular}

\section{Conclusion}

The mechanism of drawing money from the crowd has existed before and the most prominent instance of early type of crowdfunding is the building of plinth upon which the Statue of Liberty is laid. The erection of the pedestal came to pass by means of a crowdfunding which resulted from the desperate call to the crowd made by Joseph Pulitzer. The market place was secured till 1915 when acting like a catalyst, the Investments Bankers Association brought a cataclysm by telling its members they could span the laws and make solicitation via mail. A process as non-transparent as mail for securities offerings could not be policed by regulators; thus questionable stockbrokers invited themselves in the game and issued stock in pointless and fruitless companies. This led to a loss of confidence in internet transaction. In the modern era while faith has been regained in Web operations; internet trade notably e-commerce, keystones were set for not-for-profit basis money pooling. In August 2010 a group of entrepreneurs decided to take actions on the behalf of entrepreneurs but also on behalf of backers who were also upset for not being able to freely invest in their communities. Through hurdles and struggles they manage to defend the Start-up Exemption Framework at the Capitol Hill, they managed to implicate the House of Representatives and the Senate in the talks on how to design a legal environment to monitor crowdfunding in a way it helps to tackle the funding gap and the urgent need of innovation the United States of America was facing then. President Obama signed the JOBS Act 460 days after those entrepreneurs started the journey to the salvation of both investors and entrepreneurs' sides. This was the start of the crowdfunding investing, securities-based crowdfunding different from the reward-based 
one. This study mainly talked about the Equity based and the debt-based crowdfunding among all the types of crowdfunding. Equity based crowdfunding is a kind of crowdfunding based on investment, it consists of a set of people ploughing money into buying equity like stocks, bonds, in a direct way or indirectly in a nascent enterprise or an existing company. The Debt based crowdfunding is a new way of lending money to people in need of it rather than a totally neo-financial product. Within this concept, network through internet is used to straight connect lenders and borrowers; this enables fundraisers to directly borrow money or lender to directly plough money debt obligations by means of a platform.

A regulated crowdfunding is a monitored online venue where one can vend stocks and obligations to groups of people willing to invest. In addition to delineating the posture to be adopted between brokers; backers and companies, those in charge of regulating securities also control the regulated crowdfunding. It is very substantial that actors within the crowdfunding environment get to fully understand the mechanism of the system.

Coming to Africa, undisputably the penetration of crowdfunding in the financial assets market is very shallow. With a global market share of $0.07 \%$ by the end of 2018, more than $50 \%$ Crowdfunding campaigns run by Africans took place on platforms based outside the continent (P2PMarketdata, 2020). In 2018, African raised a total of $\$ 209.1$ million while China and the Asia Pacific raised a total amount of $\$ 215.4$ billion raised; the American region accounted for crowdfunding financial volume of $\$ 61.1$ billion and the European along with the United Kingdom accounted for a total amount of $\$ 10.4$ billion raised (P2PMarketdata, 2020). According to the THECROWDDATACENTER the 2019 African crowdfunding market share did shrink.

The study revealed a total of 64 crowdfunding platforms created in Africa from 2012 to 2020; with 23 in West Africa; 22 in South Africa; 10 in East Africa and 9 in East Africa. It was found that among the 23 platforms listed in West Africa; only 5 are still active nowadays. In South Africa, as per October 2020, only 12 out of the 22 platforms recorded are still active. East Africa and North Africa come with respectively 7 platforms active out of 10 and 3 platforms active out of 9 . This showed that $58 \%$ of platforms created from 2012 to 2020 are now inactive. Only 27 , about $42 \%$ of the 64 initially recorded are still functioning. This put aside, another phenomenon is that Africans prefer to run their crowdfunding campaigns on international platforms rather than on domestic platforms. In 2015, 74.38\% of the money raised through crowdfunding was done on international platforms (Disse \& Sommer, 2020). P2PMarketData also asserted that more than $50 \%$ of money raised via crowdfunding in 2018 came from international platform based. This finds an explanation in the fact that 64 of crowdfunding platforms currently operating in Africa are foreign based. The study counted 49 foreign-based platforms currently operating in Africa, almost the double of active domestic platforms. It is to be noted that on the 76 func- 
tional crowdfunding platforms in Africa, 66 operate exclusively in South Africa and East Africa while only 10 are West Africa and North Africa focused. This explains why the South African crowdfunding markets are the most developed on the continent. The study has also noted that among the platform covering the whole Africa for now, only 6 are French speaking countries focused whereas 70 are African English-speaking countries focused. The study also remarked that in West Africa, most of the projects listed on the active platforms have less than $2 \%$ of funding till their closing date. This state of affairs depicts a clear image of how much Africans are not benefiting from the fintech. Many things may be roots to this state of affairs, like internet penetration; awareness of population about crowdfunding; trust issues and lack of proper infrastructure to really implement a suitable crowdfunding system. Next studies may focus on finding factors that could influence crowdfunding adoption in Africa and think of more adapted or suitable model of crowdfunding for the continent.

\section{Conflicts of Interest}

The author declares no conflicts of interest regarding the publication of this paper.

\section{References}

Abor, J., \& Quartey, P. (2010). Issues in SME Development in Ghana and South Africa. International Research Journal of Finance and Economics, 39, 218-228.

Acs, Z. J., Desai, S., \& Hessels, J. (2008). Entrepreneurship, Economic Development and Institutions. Small Business Economics, 31, 219-234. https://doi.org/10.1007/s11187-008-9135-9

Adebayo, N. A., \& Nassar, M. L. (2014). Impact of Micro and Small Business Entrepreneurship on Poverty Reduction in Ibadan Metropolis, South Western Nigeria. International Review of Management and Business Research, 3, 1603-1626.

Adisa, T., Abdulraheem, I., \& Mordi, C. (2014). The Characteristics and Challenges of Small Businesses in Africa: An Exploratory Study of Nigerian Small Business Owners. Economic Insights - Trends and Challenges, 3, 1-14.

Afrikstart (2016). Crowdfunding in Africa, Fundraising Goes Digital in Africa: The Emergence of Africa-Based Crowdfunding Platforms (Rep.). http://afrikstart.com/report/wp-content/uploads/2016/09/Afrikstart-Crowdfunding-In Africa-Report.pdf

Agwu, M. O., \& Emeti, C. I. (2014). Issues, Challenges and Prospects of Small and Medium Scale Enterprises (SMEs) in Port-Harcourt City. European Journal of Sustainable Development, 3, 101-114. https://doi.org/10.14207/ejsd.2014.v3n1p101

Agyapong, D. (2010). Micro, Small and Medium Enterprises' Activities, Income Level and Poverty Reduction in Ghana-A Synthesis of Related Literature. International Journal of Business and Management, 5, 196-205. https://doi.org/10.5539/ijbm.v5n12p196

Ahlers, G. K. C., Cumming, D., Günther, C., \& Schweizer, D. (2015). Signaling in Equity Crowdfunding. Entrepreneurship: Theory and Practice, 39, 955-980.

https://doi.org/10.1111/etap.12157

Alessandro Nava, \& Ivo Jenik, T. L. (2017). Crowdfunding and Financial Inclusion. 
Allied Crowds (2016). Developing World Crowdfunding: Prosperity through Crowdfunding. https://cdn.filestackcontent.com/kNfFQ9IgT2ObxzjhGqUU

Arvanitis, Y. (2015). Financing for Innovation: What Can Be Done for African SMEs? Africa Economic Brief, 6, 1-8.

Ayyagari, M., Demirguc-Kunt, A., \& Maksimovic, V. (2011). Small vs. Young Firms across the World Contribution to Employment, Job Creation, and Growth (pp. 1-41). Policy Research Working Paper, No. 5631, Washington DC: World Bank. https://doi.org/10.1596/1813-9450-5631

Baeck, P., Collins, L., \& Zhang, B. (2014). Understanding Alternative Finance-The UK Alternative Finance Industry Report 2014. Cambridge Centre for Alternative Finance, (November).

Beck, T., \& Cull, R. (2014). SME Finance in Africa. Journal of African Economies, 23, 583-613. https://doi.org/10.1093/jae/eju016

Berndt, A. (2016). Crowdfunding in the African Context: A New Way to Fund Ventures. In L. Achtenhagen, \& E. Brundin (Eds.), Entrepreneurship and SME Management across Africa: Context, Challenges, Cases (pp. 31-49). Singapore: Springer Singapore. https://doi.org/10.1007/978-981-10-1727-8 3

Block, J. H., Colombo, M. G., Cumming, D. J., \& Vismara, S. (2018). New Players in Entrepreneurial Finance and Why They Are There. Small Business Economics, 50, 239-250. https://doi.org/10.1007/s11187-016-9826-6

Brixiova, Z. (2010). Unlocking Productive Entrepreneurship in Africa's Least Developed Countries. African Development Review, 22, 440-451. https://doi.org/10.1111/j.1467-8268.2010.00255.x

Carpenter, R. E., \& Petersen, B. C. (2002). Is the Growth of Small Firms Constrained by Internal Finance? The Review of Economics and Statistics, 84, 298-309. https://doi.org/10.1162/003465302317411541

Cholakova, M., \& Clarysse, B. (2015). Does the Possibility to Make Equity Investments in Crowdfunding Projects Crowd out Reward-Based Investments? Entrepreneurship Theory and Practice, 39, 145-172. https://doi.org/10.1111/etap.12139

De Bell, L. (2013). Entrepreneurship and Local Economic Growth in Emerging Markets (pp. 1-11). Utrecht: HU University of Applied Sciences.

Disse, S., \& Sommer, C. (2020). Digitalisation and Its Impact on SME Finance in Sub-Saharan Africa: Reviewing the Hype and Actual Developments, Discussion Paper, No. 4/2020. Bonn: Deutsches Institut für Entwicklungspolitik (DIE). http://dx.doi.org/10.23661/dp4.2020

EBA (2016). EBA Report on SMEs and SME Supporting Factor. www.eba.europa.eu/documents/10180/1359456/EBA-Op-2016-04++Report+on+SMEs tand+SME+supporting+factor.pdf

European Commission (2016). Crowdfunding in the EU Capital Markets Union. https://ec.europa.eu/info/publications/crowdfunding-eu-capital-markets-union en

Filmer, D., \& Fox, L. (2014). Youth Employment in Sub-Saharan Africa. Washington DC: World Bank Publications. https://doi.org/10.1596/978-1-4648-0107-5

Fleming, L., \& Sorenson, O. (2016). Financing by and for the Masses: An Introduction to the Special Issue on Crowdfunding. California Management Review, 58, 5-19.

FSD Africa (2017). Crowdfunding in East Africa: Regulation and Policy for Market Development.

http://www.fsdafrica.org/wp-content/uploads/2017/01/Crowdfunding-Regulation-in-E 
ast-Africa Final-Report.pdf

Gabison, G. A. (2015). Understanding Crowdfunding and Its Regulations. How Can Crowdfunding Help ICT Innovation? European Commission Joint Research Centre.

Gajda, O., \& Walton, J. (2013). Review of Crowdfunding for Development Initiatives. https://eurocrowd.org/wp-content/blogs.dir/sites/85/2013/10/EoD_HD061_Jul2013_Re view CrowdFunding.pdf

Gilbert, B. A., McDougall, P. P., \& Audretsch, D. B. (2006). New Venture Growth: A Review and Extension. Journal of Management, 32, 926-950. https://doi.org/10.1177/0149206306293860

GSMA Intelligence (2015). The Mobile Economy: Sub-Saharan Africa 2015. https://www.gsmaintelligence.com/research/2015/10/the-mobile-economy-sub-saharan -africa-2015/526

Gubler, Z. J. (2013). Inventive Funding Deserves Creative Regulation. The Wall Street Journal, 31 January.

Hemer, J., Schneider, U., Dornbusch, F., \& Frey, S. (2011). Crowdfunding und andere Formen informeller Mikrofinanzierung in der Projekt- und Innovationsfinanzierung. Stuttgart: Fraunhofer Verlag.

Hervé, F., \& Schwienbacher, A. (2018). Crowdfunding and Innovation. Journal of Economic Surveys, 32, 1514-1530. https://doi.org/10.1111/joes.12274

Hiller, A. (2017). An Empirical Analysis of Crowdfunding in Sub-Saharan Africa. https://slub.qucosa.de/api/qucosa\%3A16356/attachment/ATT-0/

Ichiue, H., \& Lambert, F. (2016). Post-Crisis International Banking: An Analysis with New Regulatory Survey Data. IMF Working Papers, 16, 1.

https://doi.org/10.5089/9781475566703.001

Jofre, O. A. (2016). Regulated Crowdfunding Ecosystems (pp. 117-119). The FinTech Book. https://doi.org/10.1002/9781119218906.ch30

Kirby, E., \& Worner, S. (2014). Crowdfunding: An Infant Industry Growing Fast. Staff Working Paper of the IOSCO Research Department. http://www.iosco.org/library/pubdocs/pdf/IOSCOPD459.pdf\%0Ahttp://www.iosco.org /research/pdf/swp/Crowdfunding-An-Infant-Industry-Growing-Fast.pdf

Leung, M. D., \& Sharkey, A. J. (2014). Out of Sight, out of Mind? Evidence of Perceptual Factors in the Multiple-Category Discount. Organization Science, 25, 171-184. https://doi.org/10.1287/orsc.2013.0828

Mano, Y., Iddrisu, A., Yoshino, Y., \& Sonobe, T. (2012). How Can Micro and Small Enterprises in Sub-Saharan Africa Become More Productive? The Impacts of Experimental Basic Managerial Training. World Development, 40, 458-468. https://doi.org/10.1016/j.worlddev.2011.09.013

Manyika, J., Cabral, A., Moodley, L., Yeboah-Amankwah, S., Moraje, S., Chui, M., \& Leke, A. (2013). Lions Go Digital: The Internet's Transformative Potential in Africa. http://www.mckinsey.com/industries/high-tech/our-insights/lions-go-digital-the-inter nets-transformative-potential-in-africa

Massolution (2015). The Crowdfunding Industry Report. http://www.crowdsourcing.org/editorial/global-crowdfunding-market-to-reach-344b-i n-2015-predictsmassolutions-2015cf-industry-report/45376

Mollick, E. R. (2014). The Dynamics of Crowdfunding: An Exploratory Study. Journal of Business Venturing, 29, 1-16.

OECD (2009). The Impact of the Global Crisis on SME and Entrepreneurship Financing 
and Policy Responses.

P2PMarketdata (2020). https://p2pmarketdata.com/crowdfunding-statistics-worldwide/

Paravisini, D., Rappoport, V., \& Ravina, E. (2016). Risk Aversion and Wealth: Evidence from Person-to-Person Lending Portfolios. Management Science, 63, 279-297. https://doi.org/10.1287/mnsc.2015.2317

Savarese, C. (2015). Crowdfunding and P2P Lending: Which Opportunities for Microfinance? https://www.european-microfinance.org/publication/crowdfunding-and-p2p-lendingwhich-opportunities-microfinance

The Crowd Data Center (2020a). https://www.thecrowdfundingcenter.com/data/places?location=NG

The Crowd Data Center (2020b). https://www.thecrowdfundingcenter.com/data/places?location $=\mathrm{BN}$ https://www.thecrowdfundingcenter.com/data/places?location $=\mathrm{BR}$ https://www.thecrowdfundingcenter.com/data/places?location=RW

The Crowd Data Center (2020c). https://www.thecrowdfundingcenter.com/data/places?location $=\mathrm{TZ}$

Vismara, S. (2015). Information Cascades among Investors in Equity Crowdfunding. Academy of Management Annual Meeting Proceedings, 2015, 11519. https://doi.org/10.5465/ambpp.2015.11519abstract

Vulkan, N., Astebro, T., \& Sierra, M. F. (2016). Equity Crowdfunding: A New Phenomena. Journal of Business Venturing Insights, 5, 37-49.

Wardrop, R., Rosenberg, R., Zhang, B., Ziegler, T., Squire, R., Burton, J. et al. (2016). Breaking New Ground: The Americas Alternative Finance Benchmarking Report. Cambridge: Cambridge Centre for Alternative Finance.

https://www.jbs.cam.ac.uk/faculty-research/centres/alternative-finance/publications/br eaking-new-ground/\#.VzOAkvkrK70

Wardrop, R., Zhang, B., Rau, R., \& Gray, M. (2015). Moving Mainstream the European Alternative Finance Benchmarking Report. Cambridge: Cambridge Centre for Alternative Finance. http://www.jbs.cam.ac.uk/index.php?id=6481\#.VTOtICGqpBd

Wehinger, G. (2014). SMEs and the Credit Crunch: Current Financing Difficulties, Policy Measures and a Review of Literature. OECD Journal: Financial Market Trends, 2013, 115-148. https://doi.org/10.1787/fmt-2013-5jz734p6b8jg

World Bank (2013). Crowdfunding's Potential for the Developing World. http://www.infodev.org/crowdfunding

Zhang, B., Baeck, P., Ziegler, T., Bone, J., \& Garvey, K. (2016). Pushing Boundaries: The 2015 UK Alternative Finance Industry Report (p. 56). Cambridge: Cambridge Centre for Alternative Finance. https://doi.org/10.2139/ssrn.3621312

Zhang, B., Deer, L., Wardrop, R., Grant, A., Garvey, K., Thorp, S., Gray, Y. et al. (2016). Harnessing Potential the Asia-Pacific Alternative Finance Benchmarking Report. Cambridge: Cambridge Centre for Alternative Finance.

Ziegler, T., Shneor, R., Wenzlaff, K. et al. (2019). Shifting Paradigms-The 4th European Alternative Finance Benchmarking Report. Cambridge, UK: Cambridge Centre for Alternative Finance. 